\title{
Increase In Protein, Oil, Amylose and Amylopectin Contents of Two Populations of Maize (Zea Mays L.) After Two Cycles of Reciprocal Recurrent Selection
}

\author{
${ }^{1}$ Okporie, E.O., ${ }^{1}$ S.C. Chukwu, ${ }^{2}$ G.C. Onyishi, ${ }^{1}$ L.G. Ekwu and ${ }^{3}$ G.O. Oko \\ ${ }^{I}$ Department of Crop Production and Landscape Management, Ebonyi State University, Abakaliki \\ ${ }^{2}$ Department of Crop Science and Technology, Federal University of Technology, Owerri \\ ${ }^{3}$ Department of Crop Science, University of Nigeria, Nsukka
}

\begin{abstract}
This research was conducted at the teaching and research farm of the Department of Crop Production and Landscape Management, Ebonyi State University, Abakaliki, from 2006 to 2012 cropping seasons to develop maize populations of increase protein, oil, amylose and amylopectin contents. Total of eight (8) maize varieties were used for the study and were grouped into two populations, $A$ and $B$. Population $A$ was coded $A^{1}, A^{2}, A^{3}$ and $A^{4}$ while population $B$ was coded $B^{1}, B^{2}, B^{3}$ and $B^{4}$. These two populations were genetically variable based on the time of maturity, percentage protein, oil, amylose and amylopectin. The mean protein content of the parents was $8.74 \%$ while their progenies after second cycle had percentage protein content of $13.27 \%$, showing an increase of $4.53 \%$ with mid parent heterosis of $52 \%$. The oil content of the open-pollinated maize varieties was pushed towards increasing order from $6.19 \%$ for population $A$ and $4.19 \%$ for population $B$ of the original populations to $5.61 \%$ and $5.62 \%$ for populations $A$ and $B$ respectively of the first cycle populations. These were further pushed up to $8.08 \%$ and $8.46 \%$ of the second cycle populations $A$ and $B$ respectively. The mean amylose content of the original population was $24.25 \%$ and the mean amylose content of the progenies after the first cycle was $22.02 \%$. The second cycle synthetics had mean amylose content of $19.72 \%$, showing a decrease of $4.53 \%$. The mid parent heterosis was $-9.2 \%$. The mean amylopectin content of the original population was $75.75 \%$ and the mean amylopectin content of the selected high amylopectin was $82.13 \%$, showing an increase of $6.38 \%$ over the mean amylopectin content of the original population. The breeding programme seems to be very effective in improving both the high, medium and low protein, oil, amylose and amylopectin contents of the original maize populations to all high protein, oil and amylopectin contents, except amylose, after the second cycle. In all, this method offers definite promise. Further progress in improving chemical constituents as well as other characters is theoretically possible in future cycles.
\end{abstract}

Key words: Maize, Protein, Oil, Amylose and Amylopectin, Selection.

\section{Introduction}

Maize (Zea mays L.) is the second most important cereal crop in the world economy. It is globally the top cereal in productivity and has worldwide significance as human food, animal feed and as a source of many industrial products [1]. The major seed storage proteins of maize grain belong to the Prolamin family and are called the zeins. These proteins make up $40-60 \%$ of the total endosperm protein and are so abundant that their properties have a large impact on the properties of maize grain protein as a whole. Zeins lack the essential amino acids like lysine and tryptophan, and this deficiency is reflected in the amino acid balance of the grain. Thus, plant breeding strategies for improving the amino acid balance often involve some type of modification of the zein content [2]. Quantitative genetic approaches treat amino acid levels as a multigenic trait with continuous variation, and incremental improvements are made by recurrent selection. This is analogous to the way that total protein was manipulated in the Illinois Long-term Selection experiment [3]. One approach to improving levels of essential amino acids is to select for total protein content. The problem with this approach is illustrated in the Illinois Long Term Selection populations in which a high protein population yielded less grain per land area than did a low protein population [4]. This exemplifies a well known correlation between protein content and grain yield. While nitrogen fertilization is an effective way to increase grain yield of the high protein varieties [4], increasing total protein remains a costly approach to increasing essential amino acid levels. Among all the cereals, maize is the richest source of oil. High oil (HO) maize is an important value-added maize type developed artificially, and a great contribution of modern science to maize breeding. Compared with normal maize, $\mathrm{HO}$ maize not only greatly raised the oil content and total energy level, but also increased the protein content, lysine content and other limited amino acids" content $[5,6]$. The "added value" of HO maize reflected mainly in the gain-feed-ratio of livestock, swine, and poultry $[7,8,9]$, as well as in the products of maize processing. The development of first HO maize strain (IHO) started in 1896 by Hopkins [10] was really a historical event which demonstrated the feasibility for altering oil content in maize kernel [11, 12]. Alexho HO 
maize synthetic is a good example of using single kernel recurrent selection procedure and NMR nondestructive oil analysis technique [13, 6]. Other HO maize populations developed so far include Syn.D.O (Synthetic Disease Oil) RYD (Reid Yellow Dent), YUSSS, DS7U [12].

Normal maize carbohydrate consists of about $20.0-30.0$ per cent amylose and $70.0-80.0$ per cent amylopectin. These components vary with variety of seed and environmental conditions [14]. The amylopectin of maize can be used as a substitute of cassava starch in the manufacture of pudding and adhesives while the amylose can be used to form thin, transparent films similar to cellophane and also fibres. An improvement in the chemical composition of maize grain would therefore be of great advantage in the nutritional and industrial uses of the crop [15].

Comstock et al. [16] in Obi and Onyishi [17] proposed reciprocal recurrent selection as one of the most effective breeding methods for developing improved commercial hybrids. The procedure involves simultaneous selection within two genetically variable populations. Each population serves as source material for selection from the other population. It is therefore the object of the present study to develop maize populations of increase protein, oil, amylose and amylopectin contents.

\section{Materials And Methods}

These experiments were conducted at the teaching and research farm of the Department of Crop Production and Landscape Management, Ebonyi State University, Abakaliki, from 2006 to 2012 cropping seasons. Abakaliki is located at Longitude $08^{0} 03^{1} \mathrm{E}$ and Latitude $06^{0} 25^{1} \mathrm{~N}$ at the elevation of $71.44 \mathrm{~mm}$ above sea level. It has a bimodal rainfall pattern and its rainfall per annum ranges between $1700-2000 \mathrm{~mm}$ which is from April to November. The relative humidity at dry season ranges between $60-80 \%$ and the soil belongs to the order ultisols $[18,14]$.

Materials: The original populations were obtained from the germplasm bank of the University of Nigeria, Nsukka, Enugu State, Nigeria. These include: Nsukka high yielding yellow coloured early maturing maize I \& II (NHY-YEI \& II), Nsukka high yielding yellow coloured late maturing maize I \& II (NHY-YLI \& II), Nsukka high yielding white coloured early maturing maize I \& II (NHY-WEI \& II), Nsukka high yielding white coloured late maturing maize I \& II (NHY-WLI \& II) [19]. Total of eight (8) maize varieties were used for the study. The eight varieties were planted in an isolated experimental plot containing one thousand (1000) plants with 50 rows and 20 plants per row, with a planting distance of $75 \mathrm{~cm} \times 25 \mathrm{~cm}$ between and within rows, respectively. These plots were so isolated to exclude any form of contamination or cross pollination. This exercise was necessary to confirm and re-establish the yielding performance of these varieties in Abakaliki agroecological zone. The eight varieties were grouped into two populations, A and B. Population A was coded $\mathrm{A}^{1}$ (NHY-YEI), $\mathrm{A}^{2}$ (NHY-YEII), $\mathrm{A}^{3}$ (NHY-WEI) and $\mathrm{A}^{4}$ (NHY-WEII) while population B was coded $\mathrm{B}^{1}$ (NHYYLI), $B^{2}$ (NHY-YLII), $B^{3}$ (NHY-WLI) and $B^{4}$ (NHY-WLII). These two populations were genetically variable based on the time of maturity, percentage protein, oil, amylose and amylopectin [17].

Method: The procedure for reciprocal recurrent selection as designed by Comstock et al. [16] in Obi and Onyishi [17] with modification was used. It involved the simultaneous selection from two heterogenous source populations, A and B, which were genetically variable. Each population served as source material for selection from the other population.

\section{7 cropping season (selfing and crossing)}

The experimental block for each population was $7.5 \mathrm{~m} \times 4 \mathrm{~m}$. There were four (4) rows within each block and 13 holes per row. Planting was done on flat drills with a planting distance of $75 \times 50 \mathrm{~cm}$ with two plants per hill. The selected lines from population ' $A$ ' and ' $B$ ' in each experiment were planted adjacent to each other to make cross pollination easy. Selfing is the collection and application of pollen grains from one plant to its own silks. While crossing is the collection and application of pollen grains from one plant to the silks of a different plant. A total of sixty plants of population 'A' from all the constituents in all the experiments were selfed and each self-pollinated plants was used as a male to outcross with a different selected plant from population ' $\mathrm{B}$ ' respectively. A similar procedure was followed to obtain selfs in population ' $\mathrm{B}$ ' and associated reciprocal crosses to population ' $A$ ' respectively.

The tassel-bag-shoot-bag method of hand pollination was used to self individual maize plants and also in cross-pollinating others. Ear shoots were covered one to two days before silks emerged with plastic glocery bags $28 \times 15 \mathrm{~cm}$ in size. As soon as the silks emerged and tassel began to shed pollen, the tassel bags were placed over the tassel, the open end folded and tightly fastened against the neck of the tassel stalk with paper clip. The bags were identified with a permanent marker and were left over night. At the same time of placing the tassel bags over the tassel, the ear-shoots without sufficient silks was 'cut back' with a sharp knife and covered with thin plastic glocery bag. This cut-back operation stimulated faster growth of a uniform tuft of silks. The next morning, between 9.00 and 11.00 hours GMT, the tassel-bag was shaken and then removed gently. The 
pollen grains are more viable at this period. The pollen was applied to the silks in a most careful manner that did not expose the silks to contamination with pollen from other plants during the operation. The ear shoots were then covered with the tassel bags wrapped round the culm and stapled. The tassel bags were left on the ear shoot until harvest.

\section{8 cropping season (Evaluation trial)}

A total of eighty (80) test-crosses from all the selections, involving protein, oil, amylose and amylopectin were evaluated in the performance trials. The selection was based on the protein, oil, amylose and amylopectin contents of the crosses. A Randomized Complete Block Design (RCBD) was used with three replications. In each block, the eighty (80) test-crosses were randomly allocated. The planting was done on flat drills. The experimental block was $62 \times 11$ metres with plant spacing of $75 \times 25 \mathrm{~cm}$ at one plant per hill. Adjacent replications were spaced $1 \mathrm{~m}$ apart and this gap was considered enough to eliminate interblock competition. Controlled pollination was done on all the ten plants in each row plot to avoid pollen contamination from genotypes on other rows. After harvest, the test crosses were bulked into their populations called synthetic $1\left(\mathrm{~S}_{1}\right)$. The $\mathrm{S} 1$ lines were used to continue the second cycle of the breeding programme. Similar procedure described in 2007 and 2008 cropping seasons above were repeated in the 2009 and 2010 cropping seasons to accomplish the second cycle of selection.

\section{1 cropping season (Recombination stage)}

The recombination stage was necessary in this programme to increase variability within populations by allowing each population to recombine in all possible combinations. The experimental plants were established using 7.5 x 4.5 metres plots, with 5 rows per plot and 25 hills per row. The standard plant spacings of $25 \times 75$ $\mathrm{cm}$ within and between rows, respectively, was used and the $\mathrm{S}_{2}$ selected lines were allowed to recombine within themselves in isolated plots. Equal quantities of the recombinant seeds were bulked and analysed for chemical characteristics. Recommended cultural practices were observed. Harvesting was done at 108 days after planting, when the plants had completely senesced and physiological maturity attained and passed.

\section{2 (Laboratory and data analyses)}

Determination of protein, oil, amylose and amylopectin contents of the harvested seeds were carried out in the Cytogenetics and Plant Breeding laboratory of the Ebonyi State University.

Protein Determination: The crude protein of the maize samples was determined by the Micro - Kjeldahl method as described by Pearson [20], percent protein was calculated as N\% x 6.25.

Oil Determination: Proximate system for food analysis which employs the Soxhlet's extractor as described by AOAC [21] was used in determining the percentage oil content of the maize seed samples. Percent oil was calculated as:

Weight of oil $\quad x \quad \frac{100}{1}$

Amylose and Amylopectin Determination: Amylose content in the maize samples was determined by the method described by AOAC [21]. The percent amylose was determined by comparison of Blue value of sample with that of pure amylose. The percent amylopectin was determined by subtraction on the assumption that $100 \%$ starch $=$ Amylose $(\%)+$ Amylopectin $(\%)$.

Statistical Analyses: data collected on protein, oil, amylose and amylopectin were analysed according to the procedure for Randomized Complete Block Design (RCBD) analysis of variance as outlined by Steel and Torrie [22], Obi [23] and Okporie [24]. Descriptive statistics such as mean was also calculated. Fisher's Least Significant Difference (F-LSD), as described by Obi [25] was used to compare differences between means after the preliminary F-test. Percentage protein, oil, amylose and amylopectin contents were classified according to Obi and Ihedigbo [26] and Obi and Nzeribe [27].

\section{Results}

The results obtained on protein, oil, amylose and amylopectin contents for first cycle and second cycle in each of the eight source populations are presented in Tables $1-4$.

Protein content: The protein content of the open pollinated maize varieties was pushed from $10.12 \%$ for population $A^{1}, 10.16 \%$ for population $A^{2}, 5.08 \%$ for population $A^{3}, 9.12 \%$ for population $A^{4}, 10.34 \%$ for population $\mathrm{B}^{1}, 10.21 \%$ for population $\mathrm{B}^{2}, 8.06 \%$ for population $\mathrm{B}^{3}$ and $6.83 \%$ for population $\mathrm{B}^{4}$ of the original populations to $11.79 \%, 11.70 \%, 10.80 \%, 11.00 \%, 11.30 \%, 11.80 \%, 11.95 \%$ and $11.88 \%$ for populations $\mathrm{A}^{1}, \mathrm{~A}^{2}$, $\mathrm{A}^{3}, \mathrm{~A}^{4}, \mathrm{~B}^{1}, \mathrm{~B}^{2}, \mathrm{~B}^{3}$ and $\mathrm{B}^{4}$, respectively of the first cycle populations. These were further pushed up to $13.00 \%$, $13.28 \%, 13.00 \%, 13.40 \%, 13.26 \%, 13.00 \%, 14.12 \%$ and $13.10 \%$ for populations $\mathrm{A}^{1}, \mathrm{~A}^{2}, \mathrm{~A}^{3}, \mathrm{~A}^{4}, \mathrm{~B}^{1}, \mathrm{~B}^{2}, \mathrm{~B}^{3}$ and $\mathrm{B}^{4}$, respectively, of the second cycle populations. The mean protein content of the parents was $8.74 \%$ while their 
progenies after second cycle had percentage protein content of $13.27 \%$, showing an increase of $4.53 \%$ (Table 1 ) with mid parent heterosis of $52 \%$. The analysis of variance showed that crosses evaluated in populations $\mathrm{A}^{1}, \mathrm{~B}^{3}$ and $\mathrm{B}^{4}$ were statistically different $(\mathrm{P}=0.05)$ while the crosses evaluated in populations $\mathrm{A}^{2}, \mathrm{~A}^{3}, \mathrm{~A}^{4}, \mathrm{~B}^{1}$, and $\mathrm{B}^{3}$ were the same in percentage protein content. The result showed an improved protein content after the second cycle, presumably through increase of the frequencies of favourable genes in source populations being used for improvement.

Oil content: The oil content of the open-pollinated maize varieties was pushed towards increasing order from $6.19 \%$ for population $\mathrm{A}$ and $4.19 \%$ for population $\mathrm{B}$ of the original populations to $5.61 \%$ and $5.62 \%$ for populations $\mathrm{A}$ and $\mathrm{B}$ respectively of the first cycle populations. These were further pushed up to $8.08 \%$ and $8.46 \%$ of the second cycle populations A and B respectively. The mean oil content of the parents was $5.19 \%$ while their progenies after second cycle had percentage oil content of $8.27 \%$, showing an increase of $3.08 \%$ (Table 2) with mid parent heterosis of $8.28 \%$. The analysis of variance indicated that with the exception of population $\mathrm{B}^{4}(\mathrm{P}=0.01)$, no significant variation existed among the crosses in the other populations for oil content. However, the second cycle synthetics were statistically superior in oil content to the original and first cycle populations, except population $\mathrm{A}^{4}$. The result also showed that the percentage increase of oil content at the end of second cycle ranged from 3 to 300 in the source populations.

Amylose content: The mean amylose content of the original population was $24.25 \%$ and the mean amylose content of the progenies after the first cycle was $22.02 \%$. The second cycle synthetics had mean amylose content of $19.72 \%$, showing a decrease of $4.53 \%$. The mid parent heterosis was $-9.2 \%$. The mean amylose content of selected medium amylose was $20.13 \%$, a decrease of $4.12 \%$, while that of low amylose $(19.31 \%)$ decreased by $4.94 \%$ from the original cycle populations (Table 3). No progress was made towards medium amylose but some progress was made on low amylose. The analysis of variance conducted on the populations evaluated for amylose content indicated that there was significant reduction in all the populations $(\mathrm{P}=0.05)$.

Amylopectin content: The mean amylopectin content of the original population was $75.75 \%$ and the mean amylopectin content of the selected high amylopectin was $82.13 \%$, showing an increase of $6.38 \%$ over the mean amylopectin content of the original population (Table 4). The mid parent heterosis was $8.4 \%$. The result showed a significant increase from the original population in all the eight source populations and the percentage increase ranged from 6 to 11 .

Table 1: Mean percentage protein of original populations and their progenies

\begin{tabular}{lllcccc}
\hline Source & $\begin{array}{l}\text { Popula- } \\
\text { tion A }\end{array}$ & $\begin{array}{l}\text { Popula- } \\
\text { tion B }\end{array}$ & Mid Parent & High & Medium & Low \\
\hline $\mathrm{C}_{0}$ & 8.62 & 8.86 & 8.74 & 8.74 & 8.74 & 8.74 \\
$\mathrm{C}_{1}$ & 11.32 & 11.73 & 11.53 & - & 11.53 & - \\
$\mathrm{C}_{2}$ & 13.17 & 13.37 & 13.27 & 13.27 & - & - \\
Increase & 4.55 & 4.51 & 4.53 & 4.53 & - & - \\
\hline
\end{tabular}

Heterosis for protein content for the population crosses after 2 cycles of reciprocal recurrent selection, expressed as a percentage increase of cross over mid parent was $52 \%$

Table 2: Mean percentage oil of original populations and their progenies

\begin{tabular}{lllclcc}
\hline Source & $\begin{array}{l}\text { Popula- } \\
\text { tion A }\end{array}$ & $\begin{array}{l}\text { Popula- } \\
\text { tion B }\end{array}$ & Mid Parent & High & Medium & Low \\
\hline $\mathrm{C}_{0}$ & 6.19 & 4.19 & 5.19 & 5.19 & 5.19 & 5.19 \\
$\mathrm{C}_{1}$ & 5.61 & 5.62 & 5.62 & 6.06 & 5.55 & - \\
$\mathrm{C}_{2}$ & 8.08 & 8.46 & 8.27 & 8.27 & - & - \\
Increase & 1.89 & 4.27 & 3.08 & 3.08 & - & - \\
\hline
\end{tabular}

Heterosis for oil content for the population crosses after 2 cycles of reciprocal recurrent selection, expressed as a percentage increase of cross over mid parent was $8.28 \%$ 
Increase In Protein, Oil, Amylose And Amylopectin Contents Of Two Populations Of Maize

Table 3: Mean percentage amylose of original populations and the progenies

\begin{tabular}{lllcccc}
\hline Source & $\begin{array}{l}\text { Popula- } \\
\text { tion A }\end{array}$ & $\begin{array}{l}\text { Popula- } \\
\text { tion B }\end{array}$ & Mid Parent & High & Medium & Low \\
\hline $\mathrm{C}_{0}$ & 24.50 & 4.19 & 5.19 & 24.25 & 24.25 & 24.25 \\
$\mathrm{C}_{1}$ & 21.95 & 5.62 & 5.62 & - & 22.02 & - \\
$\mathrm{C}_{2}$ & 19.85 & 8.46 & 8.27 & - & 20.13 & 19.31 \\
Increase & -4.65 & -4.41 & -4.53 & - & -4.12 & -4.94 \\
\hline
\end{tabular}

Heterosis for amylose content for the population crosses after 2 cycles of reciprocal recurrent selection, expressed as a percentage increase of cross over mid parent was $-9.2 \%$

Table 4: Mean percentage amylopectin of original populations and the progenies

\begin{tabular}{lllcccc}
\hline Source & $\begin{array}{l}\text { Popula- } \\
\text { tion A }\end{array}$ & $\begin{array}{l}\text { Popula- } \\
\text { tion B }\end{array}$ & Mid Parent & High & Medium & Low \\
\hline $\mathrm{C}_{0}$ & 75.50 & 76.00 & 75.75 & 75.75 & 75.75 & 75.75 \\
$\mathrm{C}_{1}$ & 78.62 & 78.60 & 78.61 & - & 78.61 & - \\
$\mathrm{C}_{2}$ & 81.95 & 82.30 & 82.13 & 82.13 & - & - \\
Increase & 6.45 & 6.30 & 6.38 & 6.38 & - & - \\
\hline
\end{tabular}

Heterosis for amylopectin content for the population crosses after 2 cycles of reciprocal recurrent selection, expressed as a percentage increase of cross over mid parent was $8.4 \%$

\section{Discussion}

The effectiveness of reciprocal recurrent selection as a method of improving maize synthetics is shown from the performance of the second cycle populations. The responses to selection for protein, oil and amylopectin showed a slow and steady change over the two cycles of reciprocal recurrent selection. In the first cycle, the mean protein, oil and amylopectin were greater than in the original populations but there were few plants that exceeded the highest value of the range of the original populations. According to Okporie [19], this can be interpreted as indicating that during recombination of the elite lines, the frequencies of desirable alleles for these constituents increased with a change in the proportions of different genotypes in the selected populations, but that few new genotypes had arisen. In the second cycle, more plants with values of the constituents slightly more than the upper limit of the original population range appeared, presumably as a result of the appearance of new genotypes [28, 17]. Such response is expected in characters governed by complex systems of genes (quantitative characters) each with small effects on the phenotype. The rate of change in frequency for any single gene is expected to be so small that progress toward fixation should be slow, resulting in gradual shift of the population mean, the appearance of phenotypes more extreme than any previously found in the population and little, if any, decrease in genetic variability [14]. Helms et al. [29] pointed out that if recurrent selection methods are effective, the frequency of favourable alleles is expected to increase in the population.

The results suggest favourable dominant gene action as the most important in conditioning heterosis. According to Okporie and Obi [30], if fvourable dominant genes are most important, synthetics should perform progressively more in each cycle than the original population. But if over-dominance is most important, the synthetics, especially of later cycles, should perform less, not more than the original populations.

The result of this work corroborates with the findings of Poneleit and Bauman [31], Obi and Onyishi [17], Okporie et al. [14] who all recommended breeding systems that effectively utilize additive genetic variation for alteration of either oil quantity and quality.

Selection was not effective in selection for high amylose strain. In spite of the selection practiced in the eight populations, the mean amylose generally decreased. However, the increase in the amylopectin must have affected the amylose content. Okporie and Obi [15] and Okporie et al. [14] reported that while the percentage of amylose increased, the percentage of amylopectin decreased and vice versa. The change, they observed, was followed by changes in the amount of starch, oil and protein produced. When the amylose proportion of starch decreased, there was a corresponding decrease in endosperm weight and increase in pericarp and germ weight resulting in concurrent increase in oil and protein.

In all, this method offers definite promise. Further progress in improving chemical constituents as well as other characters is theoretically possible in future cycles.

\section{References}

[1]. K. Sai, E. Satyanarayana and P. Shanthi.. Evaluation of High Oil Maize (Zea mays L.) Hybrids for Agronomic, Yield, and Quality Parameters Agricultural Research Station (Maize) Amberpet, Hyderabad-500013.A.P., INDIA. In: Proceedings of the 8th Asian Regional Maize Workshop, Bangkok, Thailand. August: 2002, 5-8.

[2]. L. Pollak, and M. Scott. Breeding for grain quality traits. USDA-ARS, Corn Insects and Crop Genetics Research Unit, Ames, Iowa 50011, USA. Maydica: 2005, $50: 247-257$. 
[3]. J. Dudley and R. Lambert. 100 generations of selection for oil and protein in corn. Plant Breeding Reviews: 2004, 24:79-110.

[4]. F. Below, J. Seebauer, M. Uribelarrea, M. Schneerman, and S. Moose. Physiological changes accompanying longterm selection for grain protein in maize. pp. 133-149. In: J. Janick (Ed.), Plant Breeding Reviews: 2004, Part 1: Long-term Selection: Maize. vol. 24. John Wiley \& Sons, Inc., Hoboken, NJ.

[5]. Y. Han, G. Parsons and D. Alexander. Nutritive value of high oil corn for poultry. Poultry Science: 1987 66: 103 -111.

[6]. T. Song. Welcome the new century of high oil corn. In: China Association of Agricultural Science Societies(ed) Prospects of Maize Genetics and Breeding for 21 century. China Agricultural Scientech Press, Beijing: 2000, P. 24-30.

[7]. K. Adams and A. Jensen. High-fat maize in diets for pigs and sows. Animal Feed Science and Technology: 1987, 17:201-212.

[8]. D. Atwell, E. Jaster, K. Moore and F. Fernando. Evaluation of high oil corn and corn for lactating cows. Journal of Dairy Science: 1988, 71:2689-2698.

[9]. M. Adams, S. Watkins, A. Waldroup, and P. Waldroup. Utilization of high oil diets for broiler chickens. J. Applied Poultry Res: 1994, 3: 146 - 165 .

[10]. C. Hopkins. Improvement in the chemical composition of corn kernel.. In: J. W. Dudley (ed) Seventy Generations of selection for oil and protein in maize. Crop Sci. Soc. of Am.: 1974, P. 1-32. Madison, Wis.

[11]. J. Dudley. Seventy generations of selection for oil and protein concentration in the maize kernel. In: J. W. Dudley (ed) Seventy Generations of selection for oil and protein in maize Crop Sci. Soc. of Am.: 1974, P. 181-212. Madison, Wis.

[12]. T. Song and S. Chen. Long term selection for oil concentration in five maize populations. National maize improvement center of China, China Agricultural University, Beijing, China 100094. Maydica: 2004, 49: 9 - 14.

[13]. D. Alexander, A. Silvel, F. Collins and R. Rodgers. Analysis of oil content of maize by wide-line NMR. Journal of American Oil Chemistry Society: 1967, 44:555-558.

[14]. E. Okporie, S. Chukwu and G. Onyishi. Phenotypic Recurrent Selection for increase yield and chemical constituents of maize (Zea mays L.). World Applied Sciences Journal: 2013, 21 (7): 994-999.

[15]. E. Okporie and I. Obi. Development of Acid Tolerant, High Yielding and High Nutritional Maize Variety after two years of Mass selection. Sci. Agric, Food Tech and Envirn.: 2004, 4: 23-30.

[16]. R. Comstock, H. Robinson and P. Harvey. A breeding procedure designed to make maximum use of both general and specific combination ability. Journal of American Society of Agronomy: 1949, (41) 360 - 367.

[17]. I. Obi, and G. Onyishi. Development of high protein populations of maize (Zea mays L.) from two cycles of reciprocal recurrent selection. Samaru J. Agricultural Research, 1994, Vol. XI, pp 63-68.

[18]. FDALR. Reconnaissance Soil Survey of Anambra State, Nigeria. Federal Department of Agriculture and Land Resources, Lagos, Nigeria. Soils Report, 1985.

[19]. E. Okporie. Development of high quality green maize (Zea mays L.) varieties under acid soil conditions of south eastern Nigeria. Unpublished Ph.D thesis submitted to the Department of Crop science, University of Nigeria, Nsukka, Nigeria. $2000, \mathrm{XV}+192$.

[20]. D. Pearson. The Chemical Analysis of Foods. 7th Edn. Churchill Livingstone Pub. Co. London and New York, 1976, pp: 575

[21]. AOAC. Official Methods of Analysis. 16th ed, 4th rev Association of Official Analytical Chemists. Gaithersburg, MD, 1998.

[22]. C. Steel, and J. Torrie. Principles and procedures of statistics. A Biometrical Approach. $2^{\text {nd }}$ ed. McGraw-Hill Book Co. Inc. New York: 1980, 481pp.

[23]. I. Obi. Statistical methods for detecting Differences between Treatment means. SANNP press limited, Enugu, 1986, 45pp .

[24]. E. Okporie. Statistics for Agricultural and Biological Sciences.. Cheston Agency Limited Enugu, 2006.

[25]. I. Obi. Statistical Methods of Detecting Differences Between Treatment Means and Research Methodology Issues in Laboratory and Field Experiments. $2^{\text {nd }}$ Edition published by AP Express Publishers Ltd, 3 Obollo Road, Nsukka, Nigeria, 2002.

[26]. I. Obi and N. Ihedigbo. Amylose, amylopectin, and oil content of some Nigerian maize cultivars. Niger. Agric J: 1987 (22) 91 100 .

[27]. I. Obi and J. Nzeribe. Variability in chemical composition of maize (Zea mays L.) after one season of intercrossing and randommating in a phenotypic recurrent selection. Niger. Agric. J: 1990, 25(2).

[28]. F. Winter. The mean and variability as affected by continuous selection for composition in corn. Crop Sci. Soc. Of Am.:1974, $95-$ F. W.

[29]. T. Helms, A. Hallauer and O. Smith. Genetic drift and selection evaluated from recurrent selection programs in maize. Crop Sci.: 1989 (29) $602-607$.

[30]. E. Okporie and I. Obi. Estimation of Genetics gains in protein and oil of eight populations of maize (Zea mays L.) after three cycles of reciprocal recurrent selection. Jour of Sc of Agric, Food Tech and Envir.: 2002, Vol. 2 pp $40-45$.

[31]. C. Poneleit and L. Bauman. Diallel analysis of fatty acids in corn oil. Crop Sci.: 1970 (10) 338 - 341. 